\title{
AUGMENTATIVE EFFECT OF FSH ON LH-INDUCED OVULATION IN THE HEN
}

\author{
MICHIHARU KAMIYOSHI AND KATUHIDE TANAKA \\ Department of Poultry and Animal Sciences, Gifu University, \\ Kakamigahara, Gifu, Japan
}

(Received 10th November 1971, accepted 17th November 1971)

\begin{abstract}
Summary. Injections of a mixture of FSH and LH into hens caused premature ovulation although each hormone was ineffective when injected alone at the same dose level. The incidence of premature ovulation increased when an ineffective dose of FSH was given with a mildly effective dose of LH. The increase was also found when FSH was injected either immediately after or $1 \mathrm{hr}$ after the injection of LH. The results suggest that FSH augments the action of $\mathrm{LH}$ to induce ovulation in the hen.
\end{abstract}

Recent findings on pituitary FsH levels during an ovulatory cycle of the hen (Kamiyoshi \& Tanaka, 1969; Imai \& Nalbandov, 1971) and on the effects of a direct application of FSH to the follicular wall of the hen's ovary (Ferrando \& Nalbandov, 1969) suggest that FsH plays an important rôle in connection with ovulation in the hen. The present experiments were carried out to elucidate the effect of FSH on LH-induced premature ovulation in normal laying hens.

White Leghorn hens weighing 1.8 to $2.2 \mathrm{~kg}$ and in their 1st or 2nd year of egg production were used. They were kept in individual cages under $14 \mathrm{hr}$ of light (05.00 to 19.00 hours) with feed and water available at all times. Only hens laying three to five eggs in a sequence (clutch) were used. Injections of FsH and LH were made into a wing vein at 15.00 hours on the day of the terminal oviposition of the sequence, i.e. $14 \mathrm{hr}$ before the expected normal ovulation of the initial ovum of the sequence. The incidence of premature ovulation was checked by digital palpations at 05.00 hours the next morning, which were repeated at 06.00 and 07.00 hours.

The injection of a mixture of $0.5 \mathrm{mg}$ NIH-FSH-s 5 with $0.005 \mathrm{mg} \mathrm{NIH-LH-s11}$ caused premature ovulation in six out of ten hens, while the injection of FSH alone or LH alone at the same dose level did not cause ovulation. Since the contamination of $\mathrm{LH}$ in $0.5 \mathrm{mg}$ NIH-FSH-S 5 is calculated to be approximately equivalent to $0.001 \mathrm{mg}$ NIH-LH-s1 1 , the mixture of FSH and LH should have contained approximately $0.006 \mathrm{mg}$ equiv. NIH-LH-s 11 as a total amount of LH. This amount of $\mathrm{LH}$ is far below the level of the effective dose for the induction of premature ovulation. The ovulation-inducing effect of the mixture of FSH and LH would not, therefore, be due to LH alone but to both FSH and LH. When mixtures of ineffective doses of FSH with a mildly effective dose of LH were injected, the incidence of premature ovulation increased (Table 1). These 
results may indicate that FSH augments the ovulation-inducing action of LH in the hen. Opel \& Nalbandov (1961) reported that FsH suppressed multiple ovulation (ovulation of smaller follicles together with the largest follicle) in hypophysectomized hens when given simultaneously with LH. The inhibitory effect of FSH was not observed in the present study.

The augmentative effect was also observed when FSH was injected either

TABLE 1

EFFECT OF SIMULTANEOUS ADMINISTRATION OF VARIOUS DOSES OF FSH WITH A MILDLY EFFECTIVE DOSE OF LH ON OVULATION IN HENS

\begin{tabular}{l|r|cc}
\hline \multicolumn{1}{c|}{ Injection* } & $\begin{array}{c}\text { No. of } \\
\text { hens }\end{array}$ & $\begin{array}{c}\text { Hens ovulating } \\
\text { No. }\end{array}$ & $\begin{array}{c}\text { prematurely } \\
\%\end{array}$ \\
\hline Saline & 6 & 0 & 0 \\
LH 0.005 mg & 5 & 0 & 0 \\
LH 0.01 mg & 14 & 4 & 29 \\
LH 0.02 mg & 29 & 10 & 34 \\
LH 0.04 mg & 11 & 8 & $73 \dagger$ \\
FSH 0.1 mg & 14 & 0 & 0 \\
FSH 0.5 mg & 12 & 0 & 0 \\
LH 0.02 mg + FSH 0.005 mg & 21 & 6 & 29 \\
LH 0.02 mg + FSH 0.02 mg & 22 & 7 & 32 \\
LH 0.02 mg FSH $0.1 \mathrm{mg}$ & 20 & 13 & $65 \dagger$ \\
LH 0.02 mg + FSH 0.5 mg & 7 & 5 & $71 \dagger$ \\
\hline
\end{tabular}

* LH as NIH-LH-s14; PSH as NIH-PSH-S6.

$\uparrow$ Significantly different $(P<0.05)$ from the group receiving 0.02 mg LH alone.

TABLE 2

EFFECT OF FSH INJEGTED BEFORE $(-)$ OR AFTER $(+)$ THE INJECTION OF LH ON OVULATION IN HENS

\begin{tabular}{|c|c|c|c|c|c|c|c|c|}
\hline$-1 h r$ & $-\frac{1}{2} h r$ & $\begin{aligned} & \text { Injec } \\
- & \frac{1}{4} h r\end{aligned}$ & $\begin{array}{l}n^{*} \text { at: } \\
0 \mathrm{hr}\end{array}$ & $+\frac{1}{4} h r$ & $+1 h r$ & $\begin{array}{l}\text { No. of } \\
\text { hens }\end{array}$ & $\begin{array}{l}\text { Hens ovt } \\
\text { No. }\end{array}$ & $\frac{m a t u r e l y}{\%}$ \\
\hline FSH & FSH & FSH & $\begin{array}{c}\mathbf{L H} \\
\mathbf{L H} \\
\mathbf{L H} \\
\mathbf{L H}, \mathbf{F S H} \\
\mathbf{L H} \\
\mathbf{L H} \\
\mathbf{L H}\end{array}$ & FSH & FSH & $\begin{array}{l}21 \\
32 \\
33 \\
17 \\
24 \\
20 \\
15\end{array}$ & $\begin{array}{r}5 \\
18 \\
15 \\
13 \\
7 \\
13 \\
4\end{array}$ & $\begin{array}{l}24 \\
56 \\
46 \\
76 \dagger \\
29 \\
65 \dagger \\
27\end{array}$ \\
\hline
\end{tabular}

* $\mathrm{FSH}-0.5 \mathrm{mg}$ NIH-FSH-s 6 ; LH $-0.02 \mathrm{mg}$ NIH-LH-s 14 .

$\dagger$ Significantly different $(P<0.05)$ from the group receiving $\mathrm{LH}$ alone.

immediately after or $1 \mathrm{hr}$ after the injection of LH (Table 2), but was not apparent when FSH was given 15 min after the injection of LH. These results suggest that FSH may exert a stimulatory effect at the start of the ovulatory process and again at a later stage. The mechanism by which FsH exerts the augmentative effect on ovulation in the hen needs further investigation, since the effect may be due to a stimulation of the secretion of positive feedback hormones from the ovary for the hypothalamo-pituitary system, which in turn cause the release of $\mathrm{LH}$ from the hen's own pituitary. 
The authors are grateful to Professor S. Yoshioka for advice, to Mr Y. Isaji and Mr R. Mai for technical assistance, and to the National Institute of Arthritis and Metabolic Diseases for the gift of hormone preparations used in this study.

\section{REFERENCES}

FERRANDO, G. \& NALBANDOV, A. V. (1969) Direct effect on the ovary of the adrenergic blocking drug Dibenzyline. Endocrinology, 85, 38.

IMAI, K. \& NALBANDOV, A. V. (1971) Changes in FsH activity of anterior pituitary glands and of blood plasma during the laying cycle of the hen. Endocrinology, 88, 1465.

KAMTYOSHI, M. \& TANAKA, K. (1969) Changes in pituitary BSH concentrations during an ovulatory cycle of the hen. Poult. Sci. 48, 2025.

Opel, H. \& NALBANDOv, A. V. (1961) Ovulability of ovarian follicles in the hypophysectomized hen. Endocrinology, 69, 1029. 